\title{
24
}

\section{CARTOONS, MEMES AND VIDEOS}

\author{
Lucien Leon
}

Prior to the 2007 federal election, which saw the emergence of web 2.0 technologies in political campaign communication and democratic discourse, political satire was mediated almost exclusively by the media troika of television, newspapers and radio. The increasing hybridisation of media platforms popularised a new form of political satire: the video mash-up. A defining moment of the pre-campaign period in 2007 was when then Prime Minister John Howard launched a new climate policy in an ill-judged and awkward first foray on to YouTube, giving tech-savvy citizen comics an opportunity to lampoon the release with their own satirical videos. This episode amplified a narrative that the incumbent government was out of touch, adding to a palpable mood for change in the electorate (Flew 2008; Williams 2008).

More recently, a newer brand of online visual satire has arrived in the form of image macros. These are culturally familiar images with brief, witty captions superimposed on them and popularly known in their replicated form as 'memes'. It has been widely remarked that memes are the new political cartoons. However, memes are produced by anonymous amateurs and gain legitimacy from repeated online transmission rather than location in legacy media. Their capacity to influence political discourse was first observed in the 2012 US presidential campaign, when 'Big Bird' and 'binders of women' memes proved so damaging to Republican candidate Mitt Romney (Tay 2014; Graeff 2015; Rentschler and Thrift 2015). 
In Australia in 2015, 'Choppergate' memes were credited with helping bring down then Speaker of the House of Representatives Bronwyn Bishop (Turton 2015; Purcell 2015). Memes have become part of the fabric of everyday political engagement (Dean 2018) but they also have the potential to be weaponised by political parties and to polarise and misinform the electorate (Renner 2017).

In this chapter, I examine how the satirical mosaic of cartoons, memes and videos circulating throughout the 2019 federal election responded to and illuminated the key themes and events, and to what extent the imagery was a reliable gauge of the public mood heading into the polls. In determining what images among the extensive volume of material should be included in the sample, I have given preference to content with broad public reach. Current newspaper readership and viewing figures validate the inclusion here of cartoons published in the editorial pages of the nation's metropolitan daily newspapers and video content broadcast or streamed on network media platforms. Also included are selected videos from the satirical 'Honest Government Ad' internet video series. Created by film and media company The Juice Media, these videos—which mimic the imagery and prosody of government advertising-have attracted millions of views across Facebook, Twitter, Instagram and YouTube and a dedicated audience of more than 300,000 subscribers.

The memes that featured in the mainstream news media were sourced almost exclusively from a pool of 618 memes mediated by six Facebook groups: ALP Spicy Meme Stash, The Simpsons Against the Liberals, Innovative and Agile Memes, Clive Palmer's Put Australia First, Australian Green Memes for Actually Progressive Teens and Australian Young Greens. These groups have an aggregated subscriber base of over 500,000 people, each of whom is a potential link to additional social networks. The sharing and reposting of these memes, as well as their intermediation with legacy news media, extend the reach of these images from beyond their partisan base to a wider mainstream audience. I have observed that the memes mediated by these groups provide a comprehensive cross-section of the more popular memes proliferating online in discussion forums and feeds on Twitter, Instagram and Snapchat, and on this basis present a viable sample for this analysis. In aligning the satirical responses with the election outcome, the images collectively frame a narrative of voters who were unimpressed with the incumbent government's infighting and lack of a coherent climate policy but not so much as to seriously consider an alternative they did not trust or did not understand. 


\section{Heading into the campaign}

In addition to offering a choice between two unpalatable options, the campaign straddled the public holiday periods of Easter and Anzac Day and was punctuated by significant newsworthy events. The retirement of a champion racehorse, the first image of a black hole, the Notre-Dame Cathedral fire, terrorist attacks in Sri Lanka, the birth of a royal baby, the Eurovision song contest, the final episodes of Game of Thrones and the death of beloved former prime minister Bob Hawke presented satirists with a rich vein of metaphors, but distracted fatigued voters from assessing platform and policy differences between the parties.

The first event to capture the public's imagination was a memerich exchange that occurred in the lead-up to the campaign. Tony Abbott's Twitter video documenting his delight at discovering a street library while doorknocking in his Warringah electorate presented a gift to citizen satirists (Plate 24.1). The $20 \mathrm{March}$ video attracted more than 1,000 replies in the first 24 hours, almost all of them mocking Abbott's ignorance of a well-established community initiative (Plate 24.2). The meme responses became the story, reinforcing a perception that Abbott was an out-of-touch conservative standing in an electorate increasingly concerned about the progressive issues of climate change and refugees. It was a free hit for his opponent, Independent Zali Steggall, before the campaign had even begun.

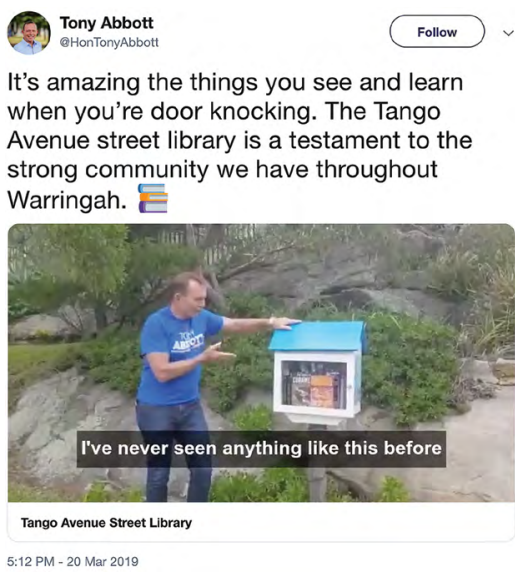

\section{Plate 24.1 Tony Abbott, Tango Avenue Street Library}

Source: Tony Abbott, Twitter account, 20 March 2019. 

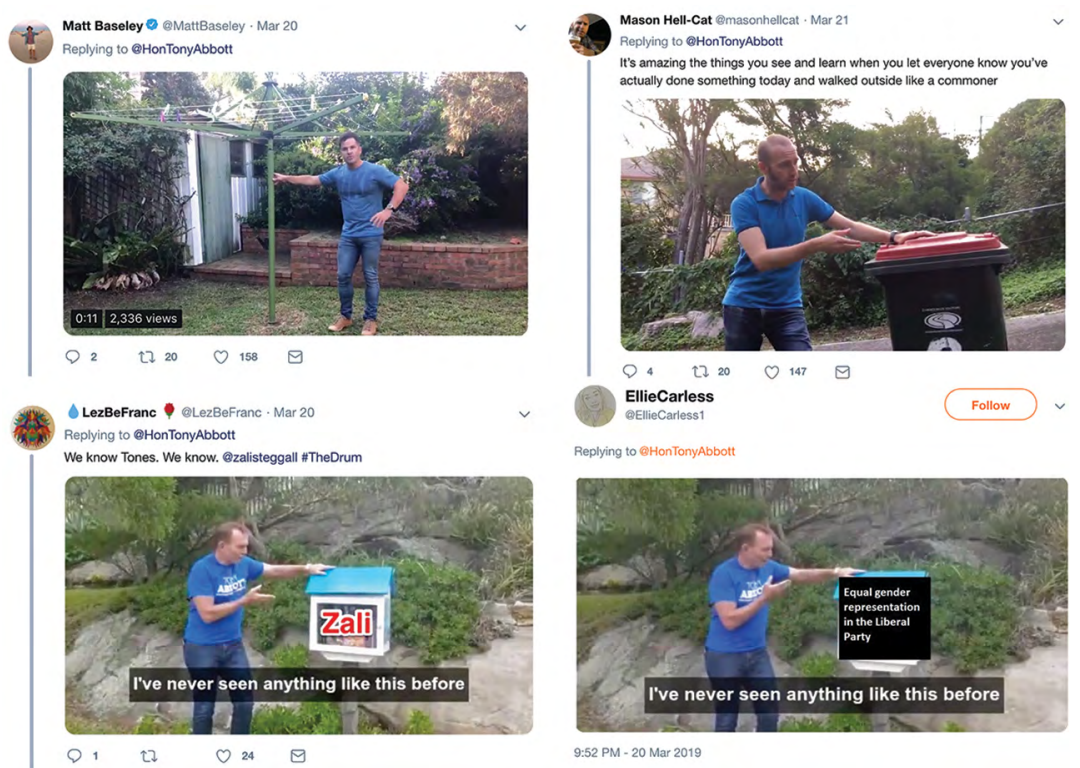

\section{Plate 24.2 Various responses to Tango Avenue Street Library,} Tony Abbott, Twitter account, 20-21 March 2019

Sources: @MattBasely; @Mason Hell-Cat; @LezBeFranc; @EllieCarless.

\section{A dirty campaign}

Two early satirical interventions by activist groups foreshadowed the ugly campaigning that was to be endemic throughout the campaign as a whole. Advance Australia's video featured their mascot suggestively rubbing up against a photoshopped billboard image of Steggall and Bill Shorten (Plate 24.3). Ten days later, activist group GetUp! misfired with its video portraying Tony Abbott as a surf lifesaver refusing to save a drowning swimmer (Plate 24.4). Both videos were retracted after public outcry. Cartoonist Jon Kudelka sums up the efforts of the respective groups with his own satirical intervention (Plate 24.5). 


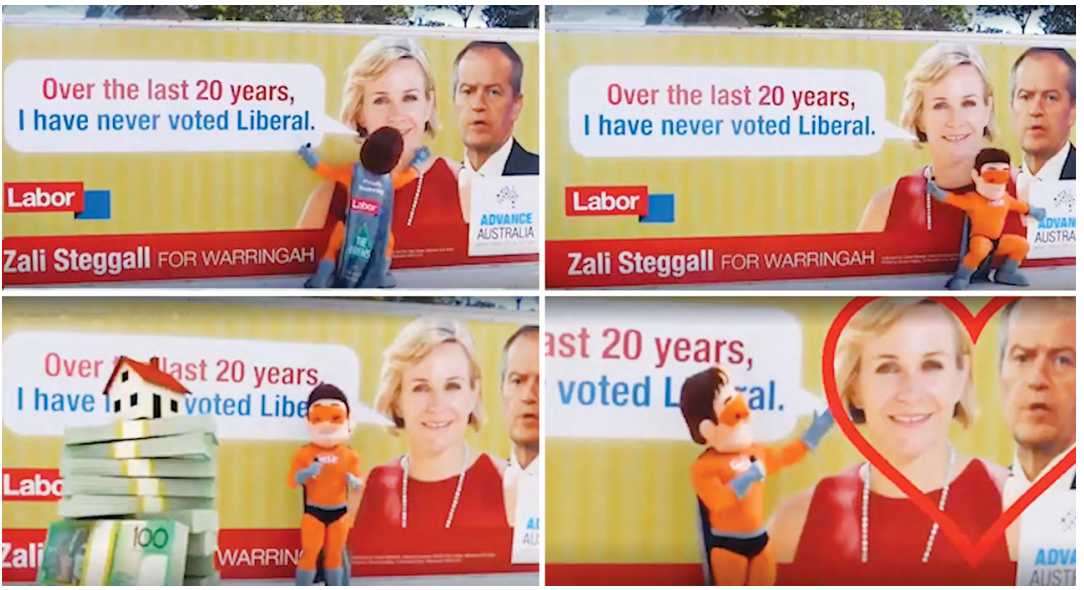

Plate 24.3 Still showing an image sequence from Captain GetUp video, 13 April 2019

Source: www.news.com.au/video/id-5348771529001-6026202939001/captain-getupaccused-of-sexism-with-billboard [video removed].
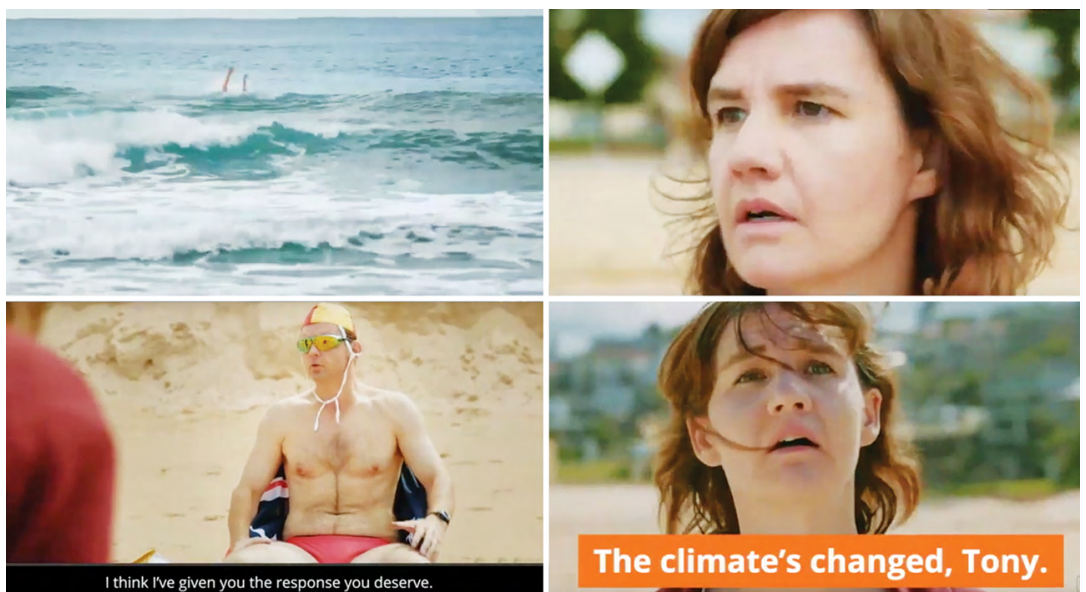

Plate 24.4 Still showing an image sequence from GetUp! Australia video, 23 April 2019

Source: $w$ ww.youtube.com/watch?v=3-MKqCGY5bs [video removed]. 


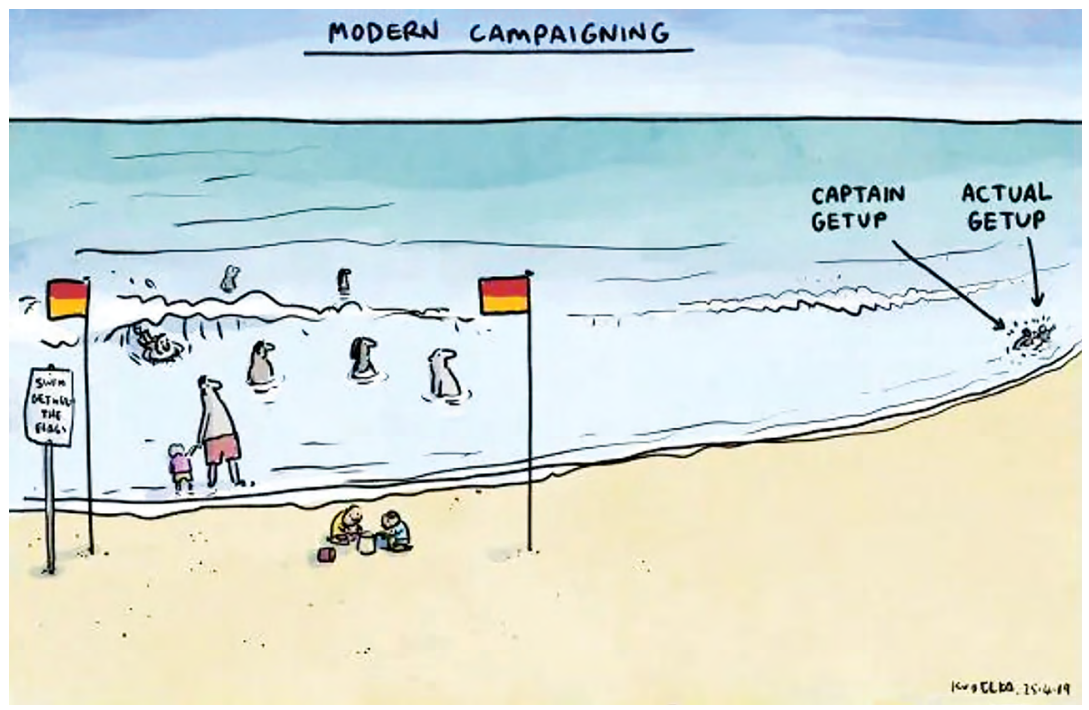

Plate 24.5 Jon Kudelka, 'Modern campaigning'

Source: The Australian, 25 April 2019.

\section{Voter uninterest and pre-polling}

When Bill Shorten bit into his democracy sausage on 18 May, he declared that it tasted like 'a mood for change' (Coughlan 2019). Every major opinion poll seemed to confirm this judgement and the bookies were not even at the institutional sizzle; they had paid out punters betting on a Labor victory three days earlier. And yet the supposed mood for change was not borne out by the major parties' seat-by-seat polling, the reporting of journalists 'on the road' or citizen chatter on social media (Koslowski 2019)—all of which indicated that the prevailing flavour was one not of change but of uninterest. Two cartoons, by David Pope and Michael Leunig, bookend the campaign period and sum up the apathy that undermined Shorten's case to voters (Plates 24.6 and 24.7). 


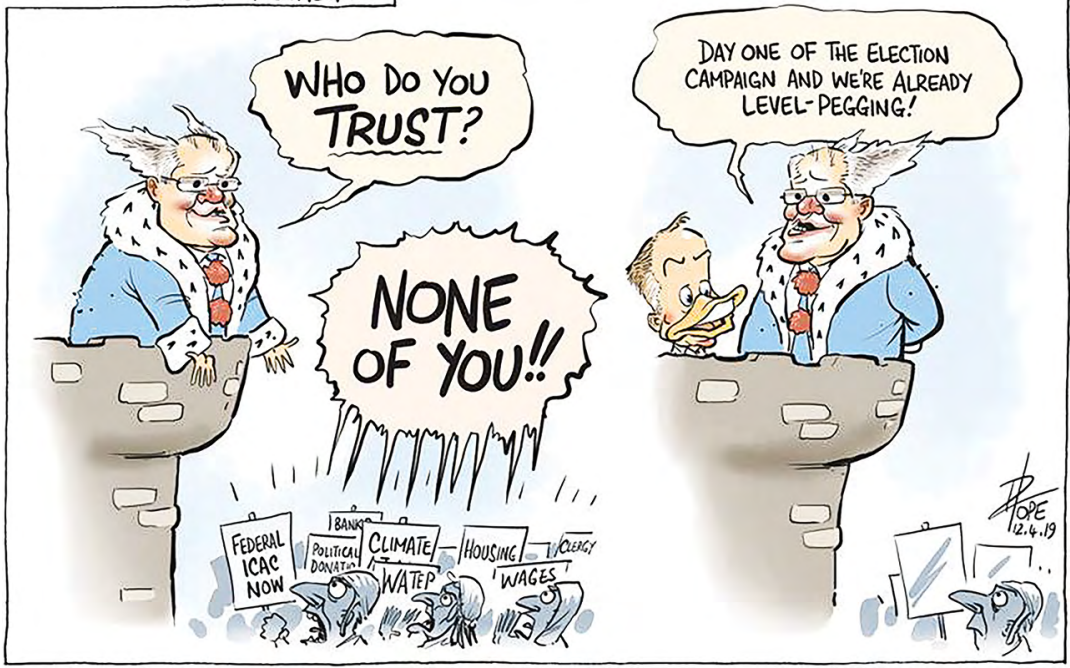

Plate 24.6 David Pope, 'Economic inputs of Australia!'

Source: The Canberra Times, 12 April 2019.

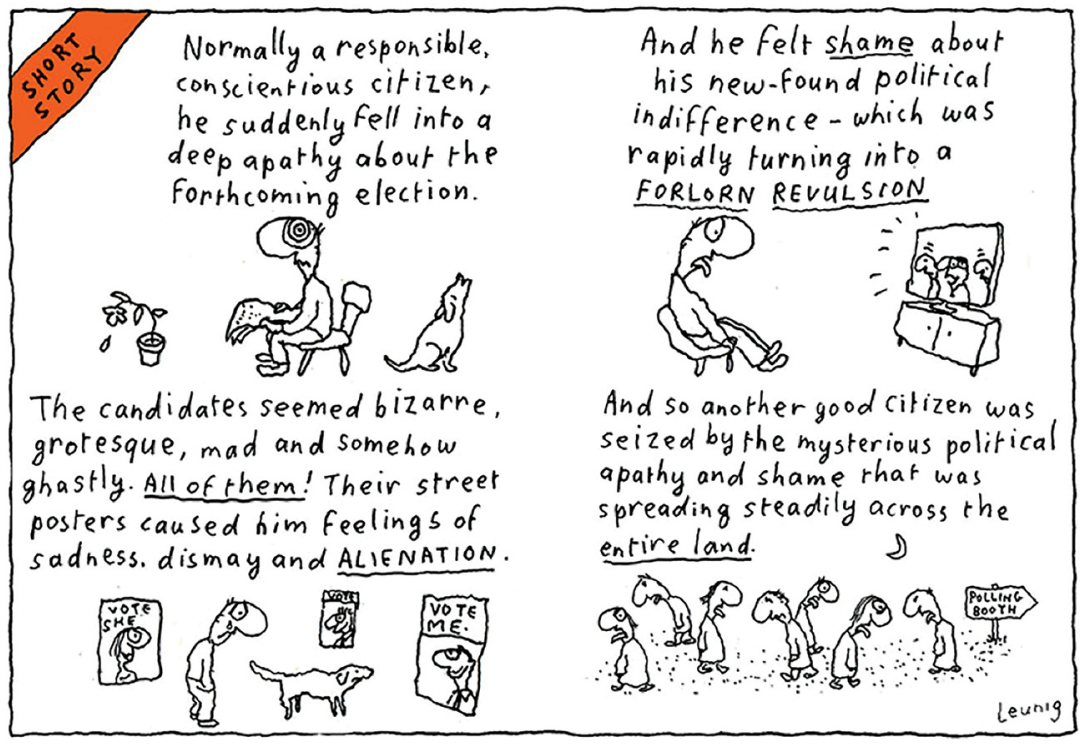

Plate 24.7 Michael Leunig, 'Short story'

Source: The Age, [Melbourne], 15 May 2019. 


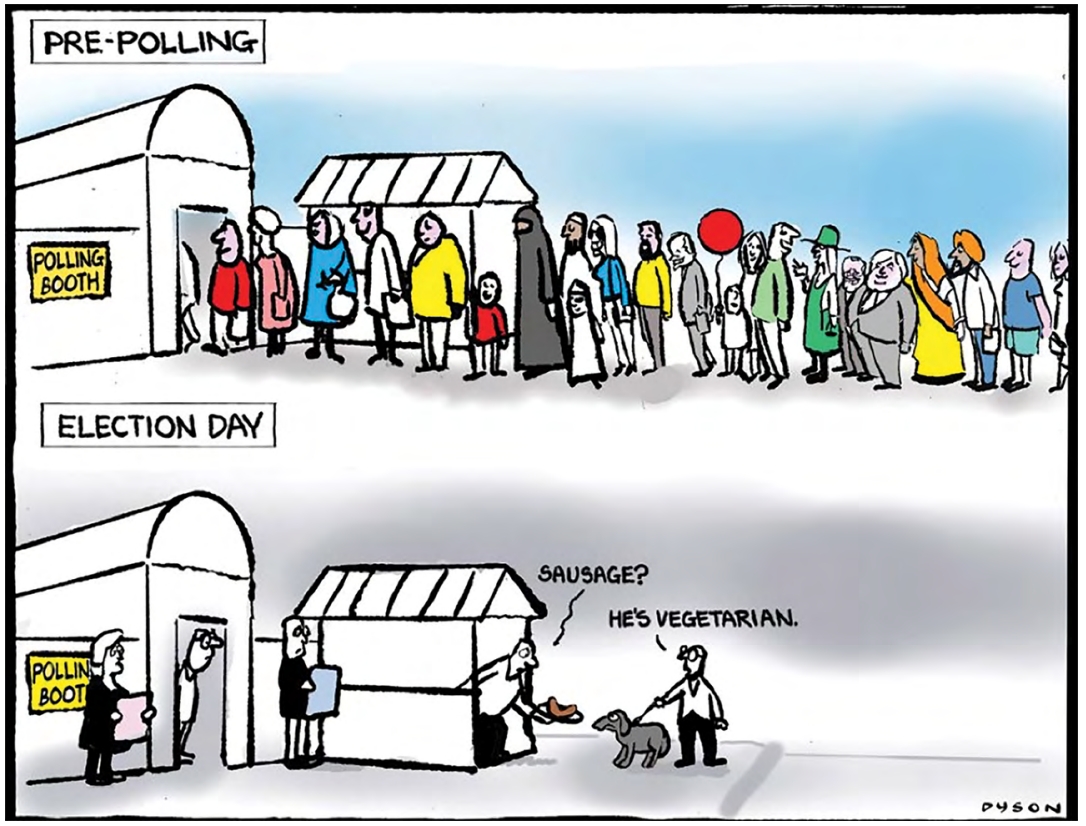

Plate 24.8 Cartoon by Andrew Dyson

Source: The Age, [Melbourne], 27 April 2019.

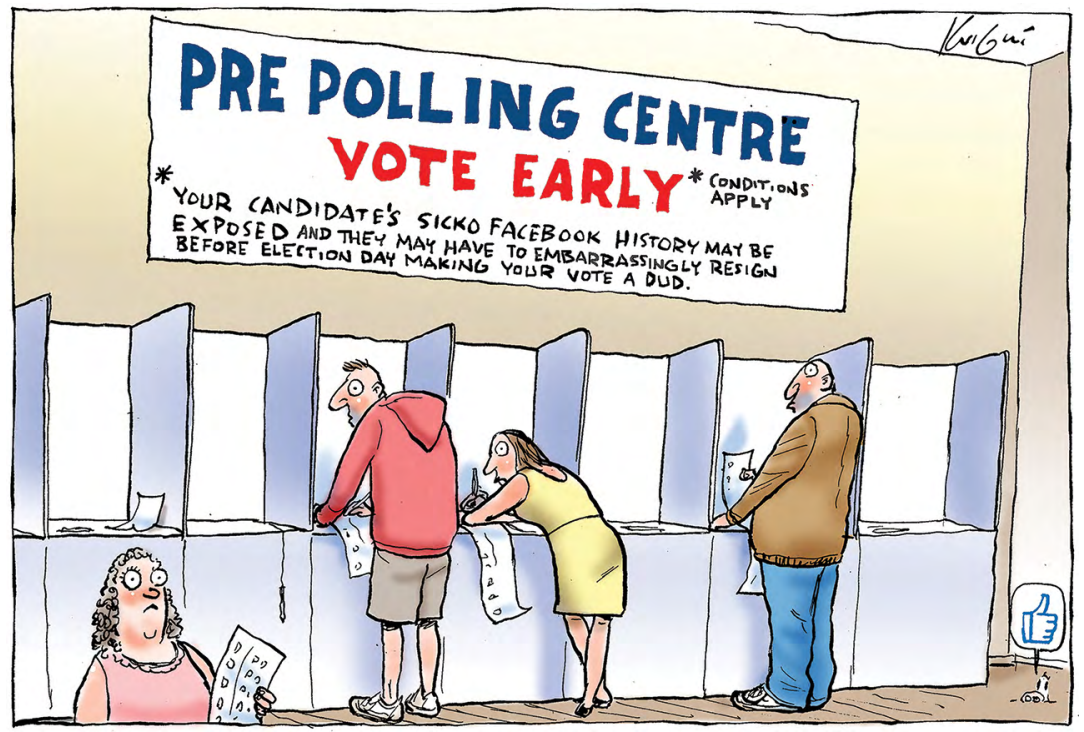

Plate 24.9 Cartoon by Mark Knight

Source: Herald Sun, [Melbourne], 5 May 2019. 
Voter uninterest was signalled early and throughout the campaign by an unprecedented number of people casting pre-poll votes. Nearly 5 million people cast an early ballot, with the Coalition doing significantly better than Labor among early voters (see Chapter 9, this volume). Pre-polling attracted attention from cartoonists but was not addressed at all in memes. Andrew Dyson (Plate 24.8) anticipated this dynamic with his portrayal of the lone polling-day voter as a progressive with a vegetarian dog, while Mark Knight (Plate 24.9) commented on the potential ramifications of pre-poll voting on candidate choice by touching on another one of this election's features: the disendorsement of candidates by their party due to compromising social media histories.

\section{The leaders}

Bill Shorten and Scott Morrison entered the campaign with substantial baggage. Despite an ambitious and expansive suite of policies, Shorten's wooden public persona compounded residual trust issues over his role in the downfall of two Labor prime ministers. A disastrous intervention by Sydney's Daily Telegraph about Shorten's mother afforded him the opportunity for a heartfelt rebuttal that connected with many voters, but its humanising potential was neutralised by the sympathy directed at Morrison after an attempted egging at a Country Women's Association event the same day. David Rowe, in inimitable style, articulates both Shorten's inability to cut through to an uninterested electorate and the fickle nature of public opinion (Plates 24.10 and 24.11). On the incumbent's side, Morrison was an accidental prime minister bereft of a reform agenda and commanding an unpopular and chaotic ministry. The cartoons by Pat Campbell (Plate 24.12) and Cathy Wilcox (Plate 24.13) neatly capture the bunker vibe underscoring Morrison's presidential-style campaign. A high proportion of memes appearing on the main party-affiliated Facebook sites personalised the campaign by focusing on these same perceived weaknesses of the party leaders (Plate 24.14 and 24.15). 


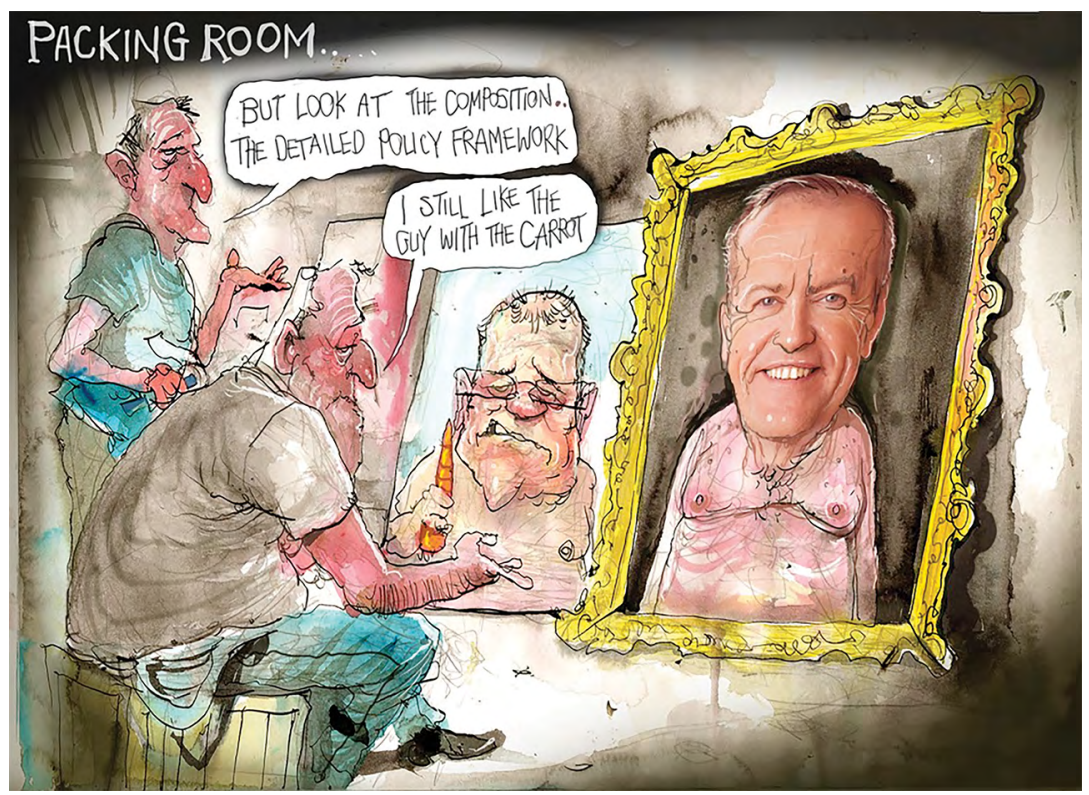

Plate 24.10 David Rowe, 'Packing room ...'

Source: Australian Financial Review, 3 May 2019.

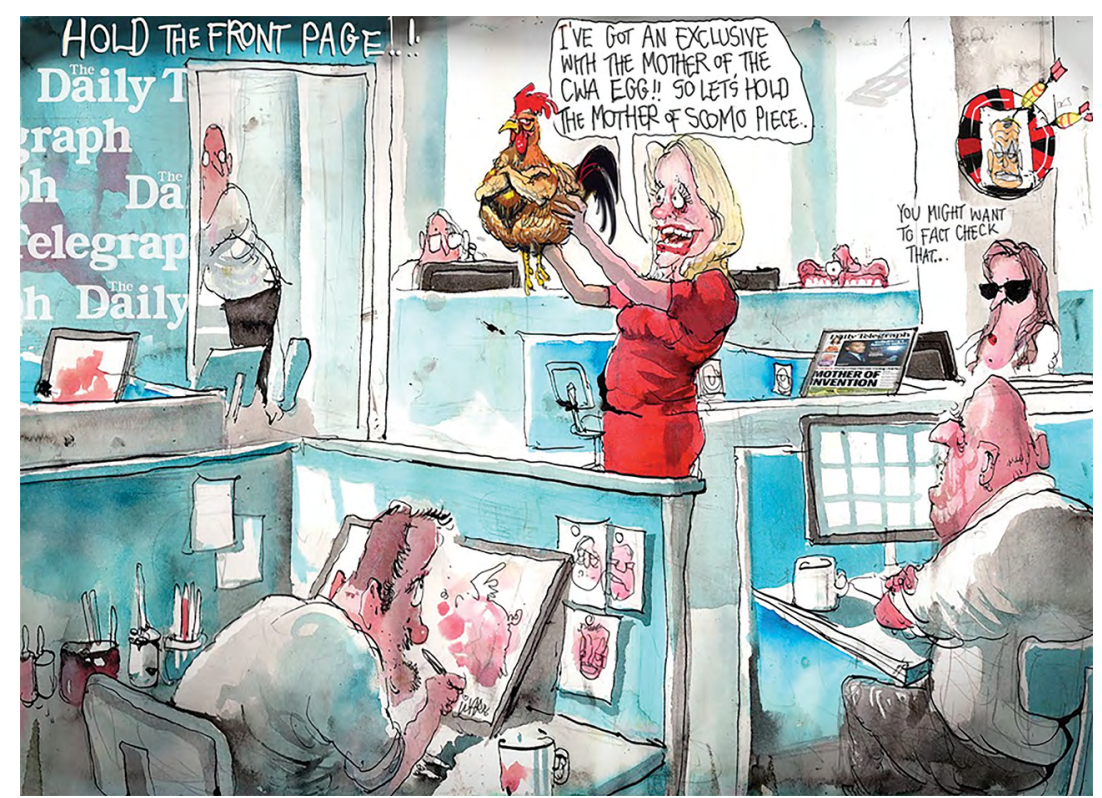

Plate 24.11 David Rowe, 'Hold the front page!'

Source: Australian Financial Review, 9 May 2019. 


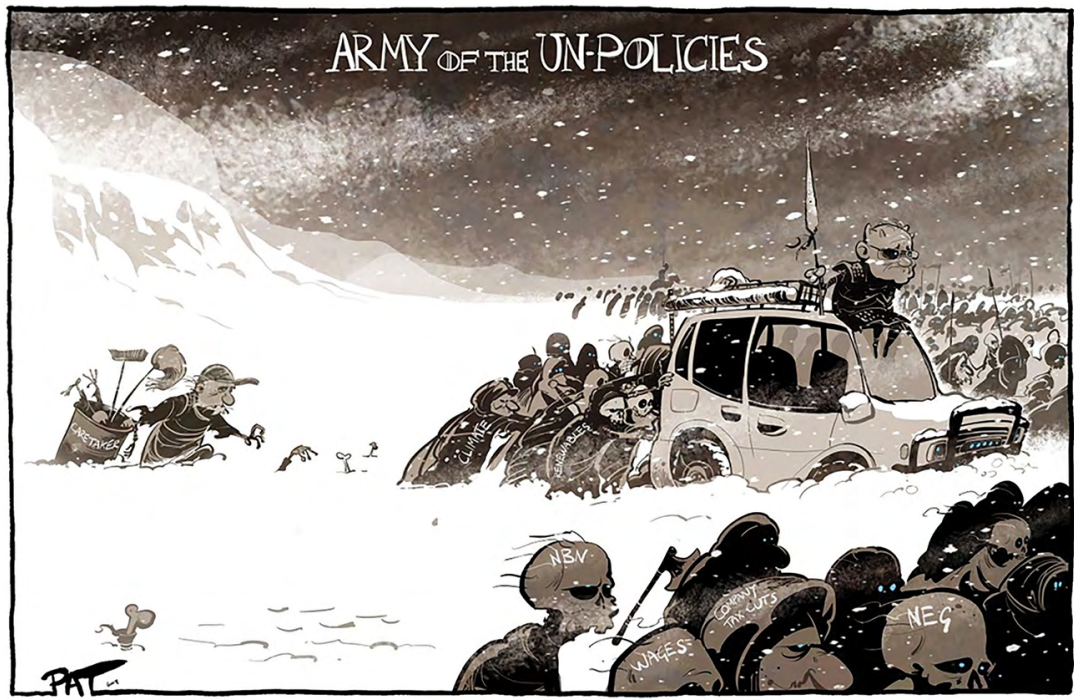

Plate 24.12 Pat Campbell, 'Army of the un-policies'

Source: The Canberra Times, 15 April 2019.

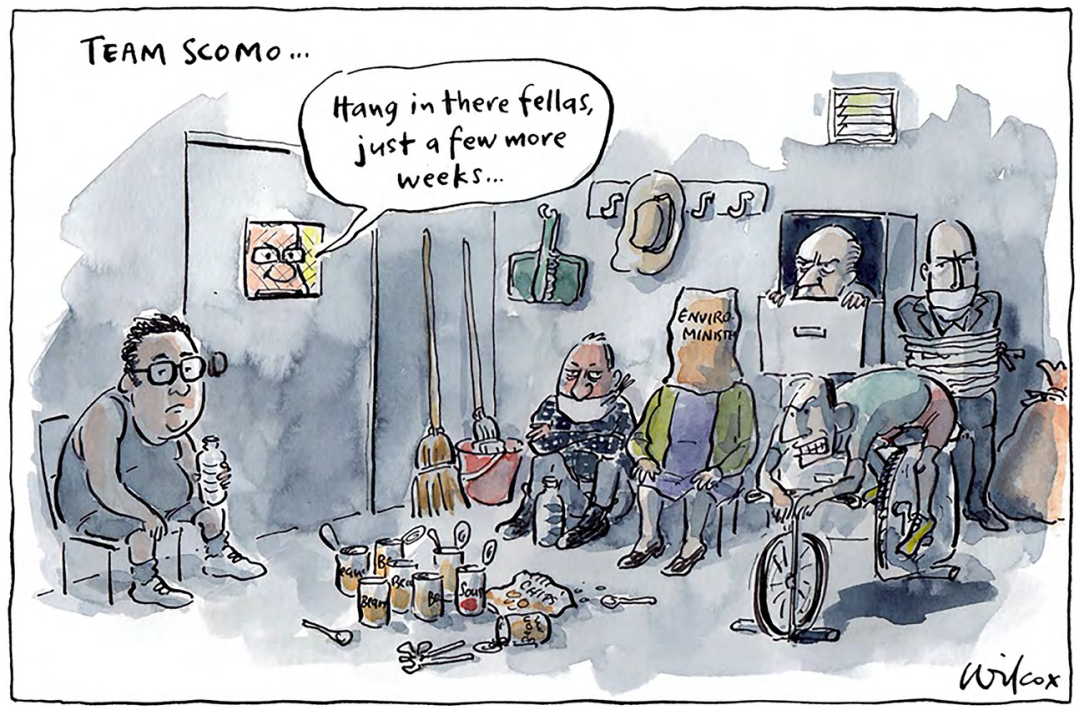

Plate 24.13 Cathy Wilcox, 'Team ScoMo'

Source: Sydney Morning Herald, 1 May 2019. 
literally no one:

Bill:

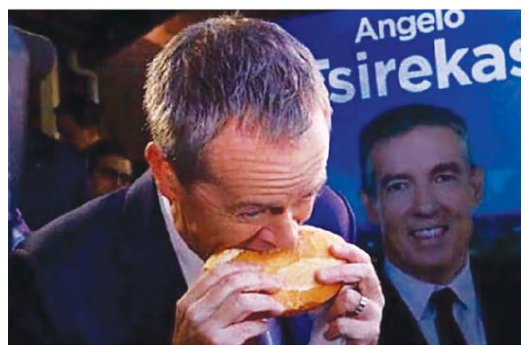

Plate 24.14 Meme by Innovative and Agile Memes

Source: Facebook, 23 April 2019.

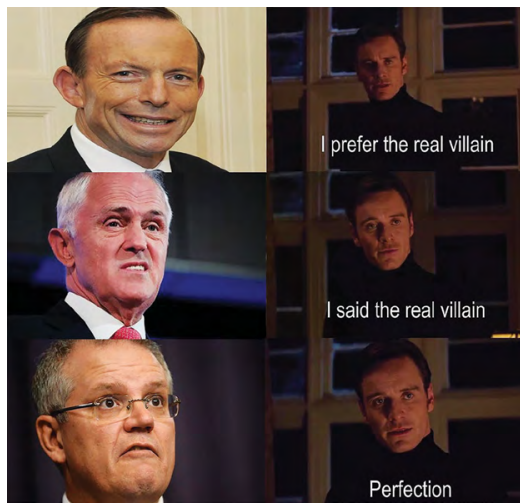

Plate 24.15 Meme by ALP Spicy Meme Stash

Source: Facebook, 5 May 2019.

Two companion videos produced by the ABC's satirical news program The Weekly with Charlie Pickering highlighted the challenges each of the leaders faced in elevating their public image. The first video, 'Australian Labor Party Robotics', presents Shorten as 'The Billbot', an automaton whose failed programming initiates maladroit behaviour that fails to convince voters that it is human (Plate 24.16). Many of the awkward actions and utterances satirised in this clip as examples of a malfunctioning robot were also featured in an unembellished montage released by the Liberal Party on the same day as The Weekly's clip. 'Ladies and Gentlemen, Mr Bill Shorten' became the most-watched video produced by a political party, garnering more than 1.1 million views. The reductive characterisation of Shorten's public persona in the two videos leverages the popular perception that he is not authentic, not 'one of us'. In reference to the consistently poor personal approval ratings that plagued Shorten throughout his tenure as Opposition leader, Sunrise program host David Koch observed in an interview with Shorten that 'the more people see you, the more they don't like you' (Seven Network 2019).

The second $\mathrm{ABC}$ video, 'Rebranding Scott Morrison', presented a fictitious public relations (PR) company's response to the brief of 'turning a terminally unpopular politician into a vote winner' (Plate 24.17). The clip lists all the electoral challenges facing Morrison, from his refusal to support a banking royal commission to the perception that 'the party's got a problem with women' - and frames a PR strategy to mollify them in the minds of voters. Says one half of the PR duo: 
The hardest part of this brief was that if ScoMo talks about the past it reminds voters about the spills, but if he talks about the future it could trigger another one. He needs to keep voters hypnotised in the present.

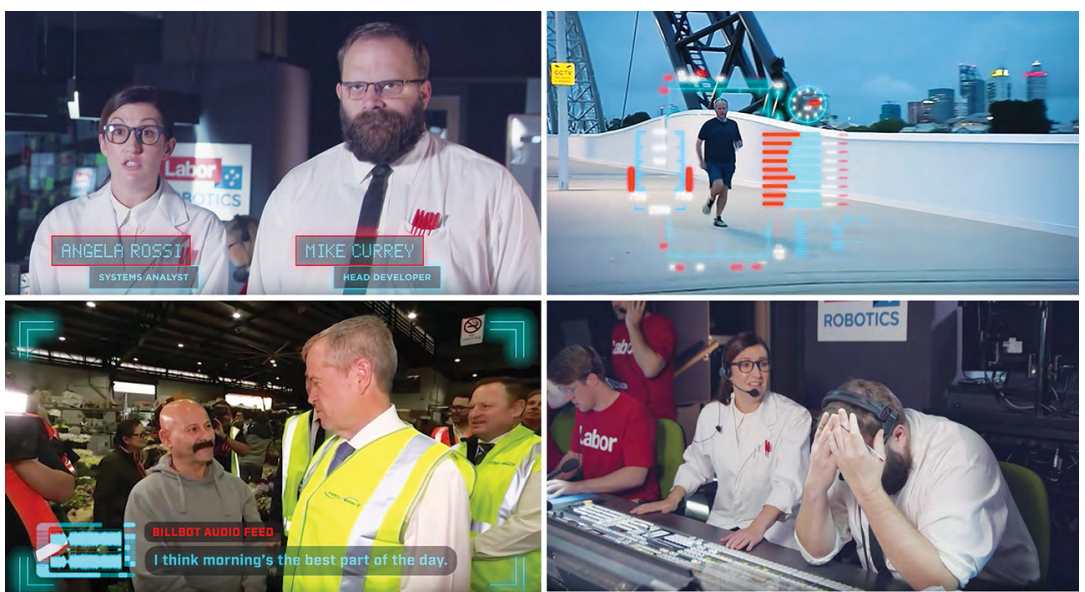

Plate 24.16 Still showing an image sequence from The Weekly with Charlie Pickering's mash-up video 'Australian Labor Party Robotics', 10 May 2019

Source: www.youtube.com/watch?v=ecbDqnsdfVM.
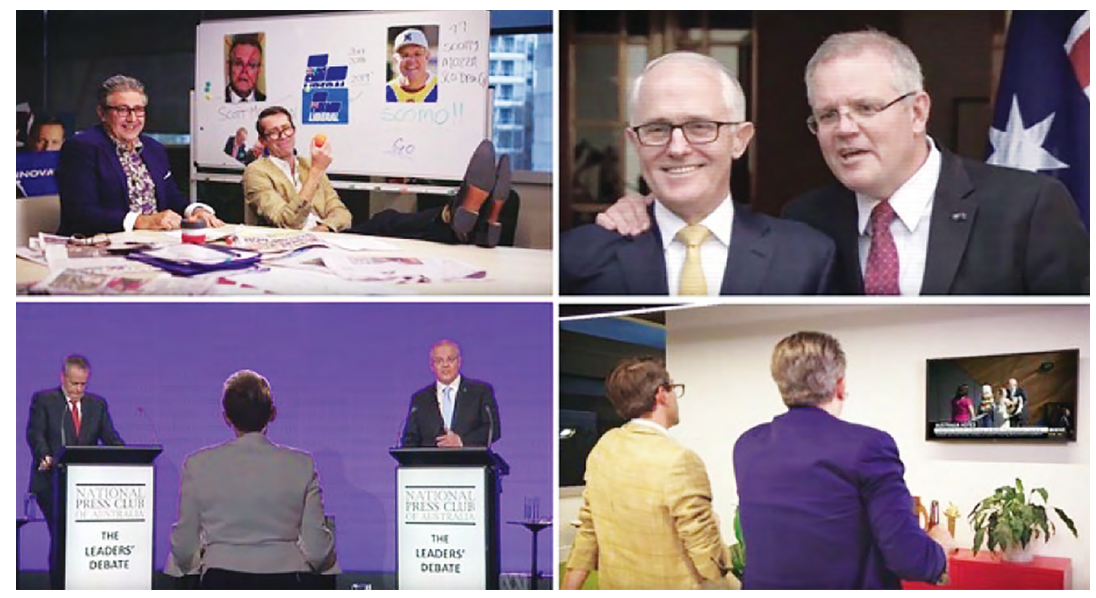

Plate 24.17 Still showing an image sequence from The Weekly with Charlie Pickering's mash-up video 'Rebranding Scott Morrison', 15 May 2019

Source: $w w w . y o u t u b e . c o m / w a t c h ? v=5 c \_U O 5 P C k l Y \& t=6 s$. 
The premise of the clip, which was viewed nearly 800,000 times on Facebook, cleverly alludes to Morrison's former role in successful marketing campaigns for New Zealand and Australian tourism. Fashioning himself as a folksy, daggy dad and reducing his platform to a lexicon of catchy phrases were deft smoke-and-mirrors manoeuvres that camouflaged ministerial liabilities and paucity of vision.

\section{The climate election}

Alongside the respective personal characteristics of the leaders, the climate issue dominated progressive social media (Plates 24.18 and 24.19), but it did not take long for Labor's climate platform-a putative party strength - to be derailed. When the ALP led into the campaign with a proposed target on electric car sales, small business minister Michaelia Cash immediately reframed the initiative as a threat to tradesmen, announcing that the Liberal Party would 'stand by our tradies' and 'save their utes' (ABC 2019a). Kudelka illustrates the implied messaging: that snide, sanctimonious, inner-city progressive types want to run over the livelihoods of honest, hardworking Aussies (Plate 24.20).

Nurse: Sir you've been in a coma since 2013

Me: oh boy I can't wait to see the action the government has taken on climate change

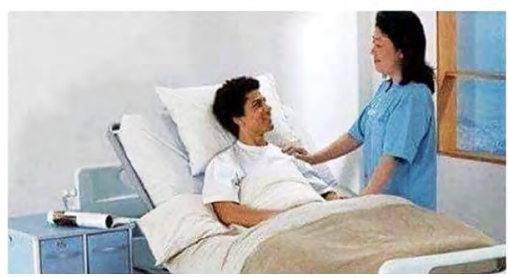

Plate 24.18 Meme by ALP Spicy Meme Stash

Source: Facebook, 19 April 2019. when the Liberals know that climate change exists but say it's too expensive to do anything about it

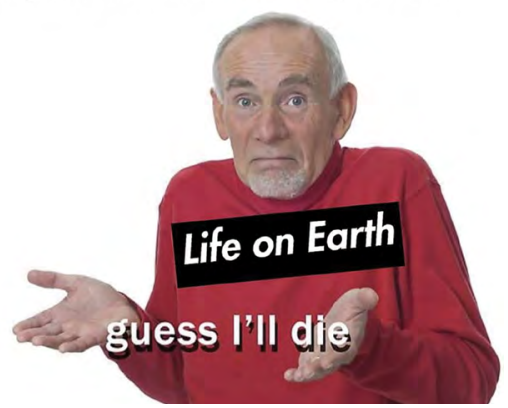

Plate 24.19 Meme by Australian Young Greens

Source: Facebook, 2 May 2019. 


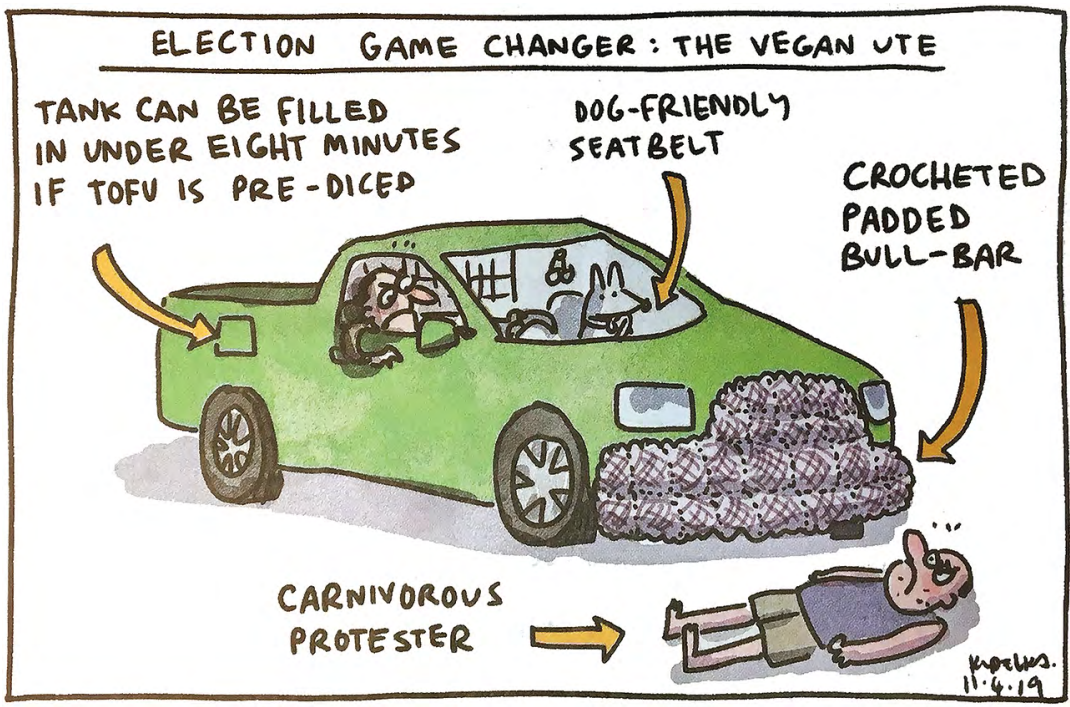

Plate 24.20 Jon Kudelka, 'Election game changer: The vegan ute'

Source: The Australian, 11 April 2019.

Variations of this narrative were effectively transferred to every plank of Labor's climate platform-most notably, with respect to the proposed Adani Carmichael coalmine. Labor's ambivalent support of the project offered little reassurance to voters concerned about climate change, on the one hand, or those prioritising jobs in the mining sector on the other.

The 'Adani convoy' galvanised the positions of both sides and left Labor with no clear strategy for securing the Queensland seats needed to win government (see Chapter 11, this volume). At the same time, Labor's decision to support fracking in the Northern Territory's Beetaloo Basin and promise of $\$ 1.5$ billion towards a gas pipeline development in northern Australia left it open to accusations of inconsistency on greenhouse emissions (ABC 2019c). In his cartoon, Dyson (Plate 24.21) reminds us that Morrison was managing his own balancing act, toning down his support for the Adani mine so as not to alienate climate-conscious Victorian voters. With both leaders having little to say about an issue that was expected to dominate the campaign, David Pope draws on Anzac imagery to depict this curious truce (Plate 24.22). 


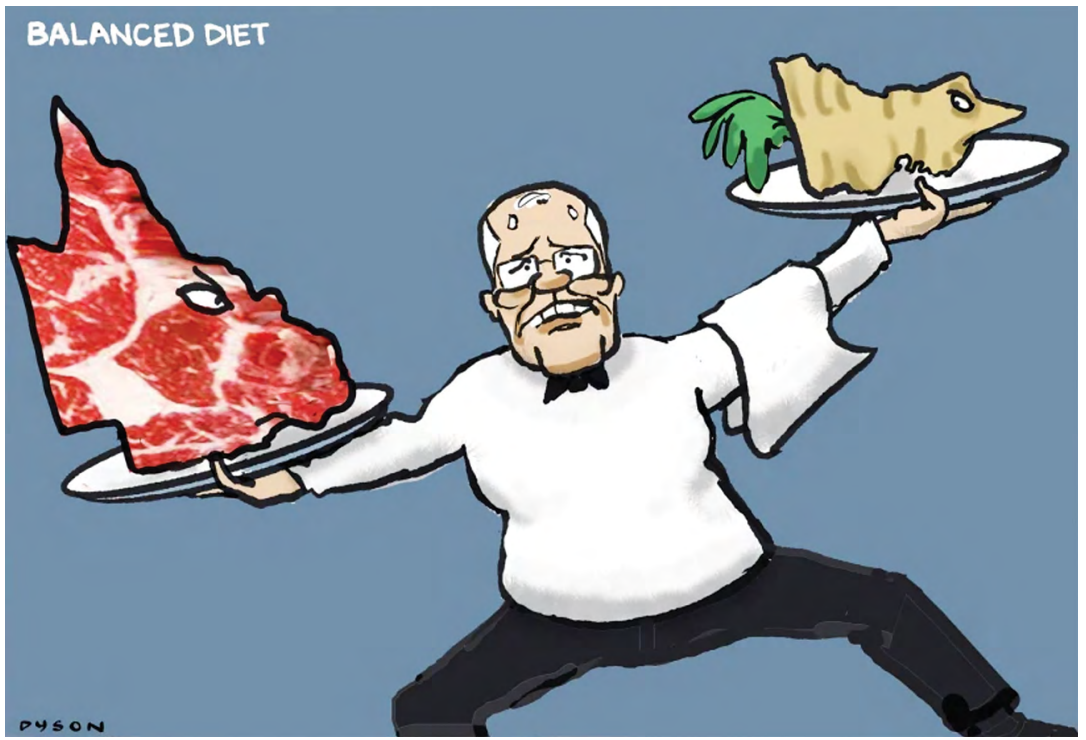

Plate 24.21 Andrew Dyson, 'Balanced diet'

Source: The Age, [Melbourne], 11 April 2019.

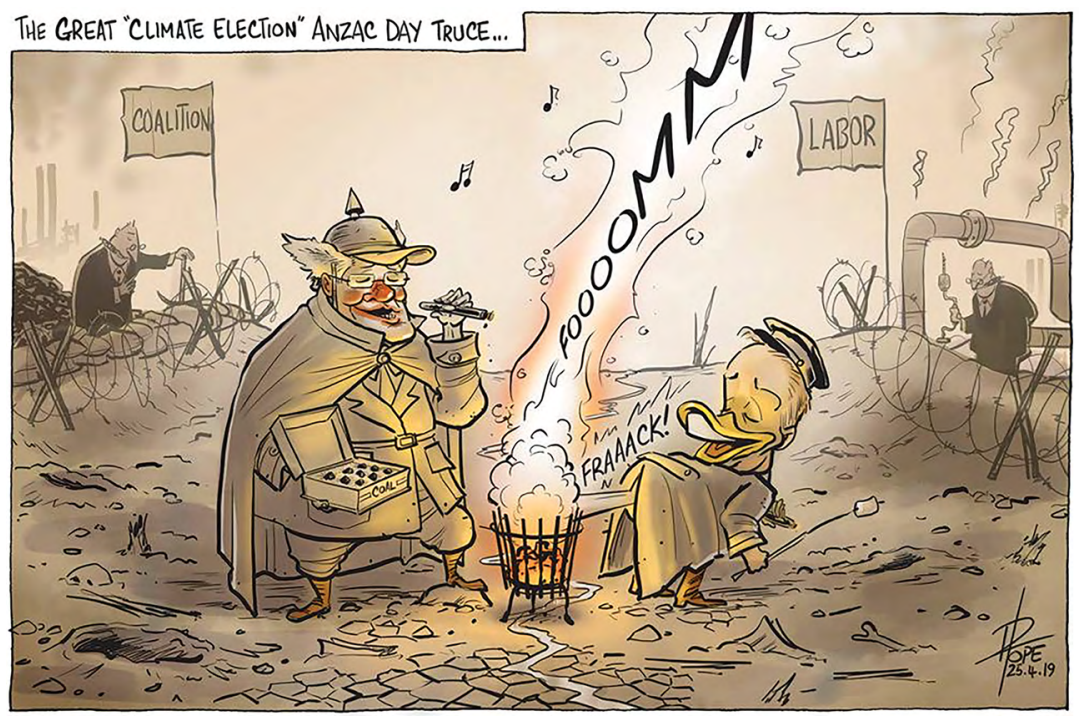

Plate 24.22 David Pope, 'The great "climate election” Anzac Day truce ...'

Source: The Canberra Times, 25 April 2019. 
Shorten's inability to provide clear costings on Labor's climate change commitments in a tetchy exchange with journalists on day five of the campaign gifted Morrison the opportunity to paint Labor as economically irresponsible. Coupled with Shorten's gaffe the following day over taxes on superannuation and another gaffe in the second week over tax cuts for people earning more than $\$ 250,000$ a year, Morrison was able to conflate broad public distrust of Labor's economic management with broad public distrust of Shorten. Mark Knight's cartoon at the start of the Easter weekend summarises Shorten's predicament (Plate 24.23), while meme creators seized on Shorten's interview presentation as being indicative of his policies as a whole (Plate 24.24).

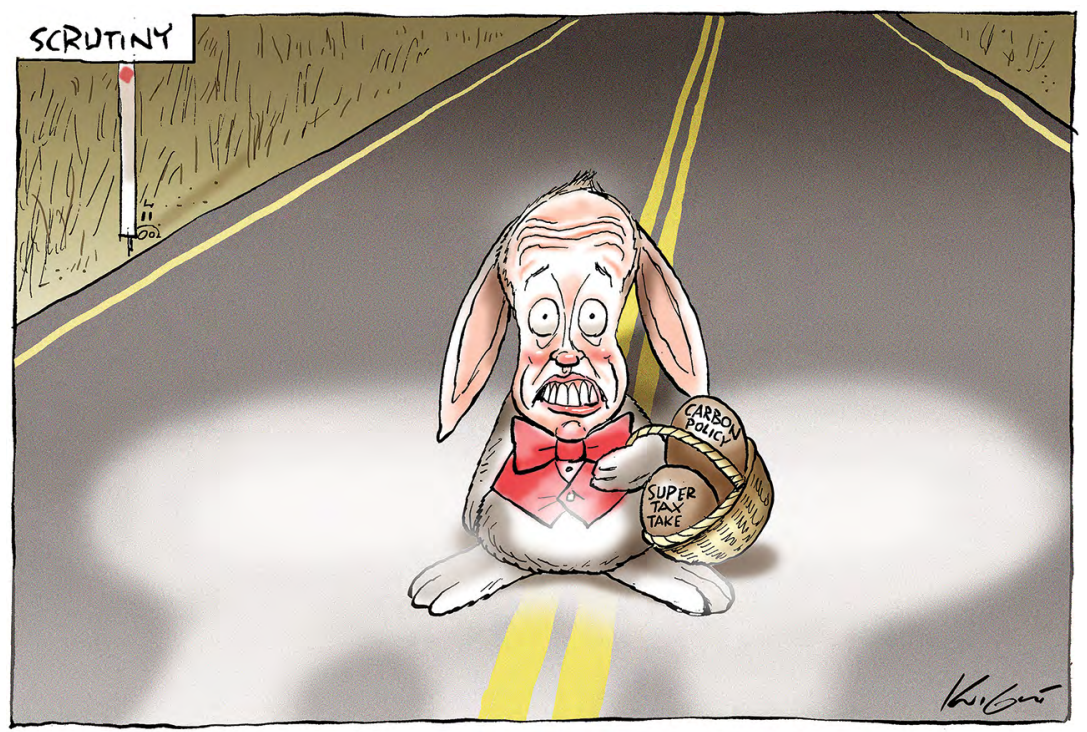

Plate 24.23 Mark Knight, 'Scrutiny'

Source: Herald Sun, [Melbourne], 19 April 2019. 


\section{Who's the bigger flake?}

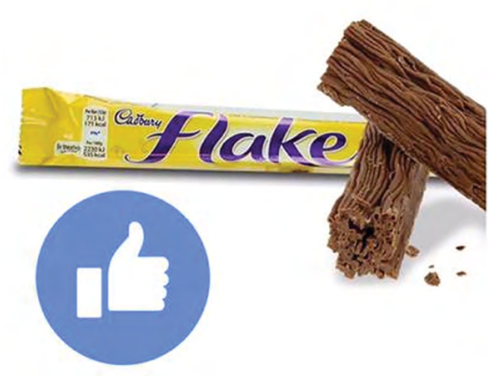

an actual flake

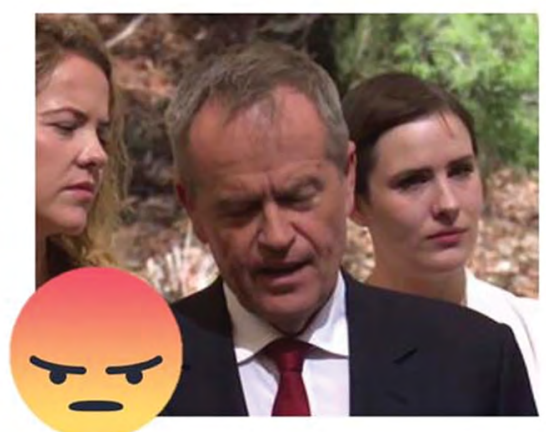

\section{Bill after 15 seconds}

in front of cameras

Plate 24.24 Innovative and Agile Memes, 'Who's the bigger flake?'

Source: Facebook, 28 April 2019.

\section{Baby boomers}

Morrison presented himself as not just the leader who could deliver job security to 'hardworking Australians'; he was also the leader who could deliver incentives and rewards to workers and protect the entitlements of self-funded retirees and pensioners. In a move telegraphed a year earlier when he was still treasurer, Morrison gathered up Labor's tax policies - including the aforementioned curtailing of superannuation tax concessions, withdrawal of dividend imputation (or 'franking') credits, cessation of negative gearing and winding back of the capital gains tax concession-and neatly repackaged them as a 'retiree tax'. The Australian's Johannes Leak - in characteristically partisan style-shows Shorten winning a debate few people seemed to care about but losing an argument a great many people cared very much about (Plate 24.25). The idea that Shorten was robbing pensioners gained traction (Plate 24.26). By the time someone finally managed to explain in simple terms what franking credits were, voters had stopped listening (Plate 24.27). 

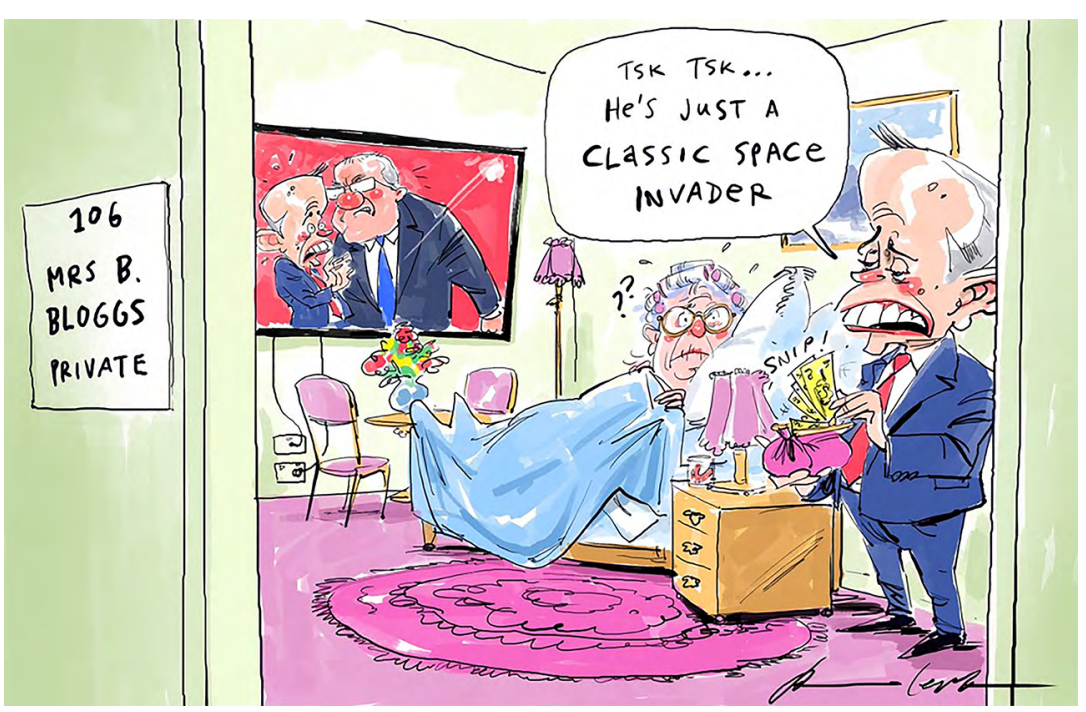

Plate 24.25 Cartoon by Johannes Leak

Source: The Australian, 6 May 2019.

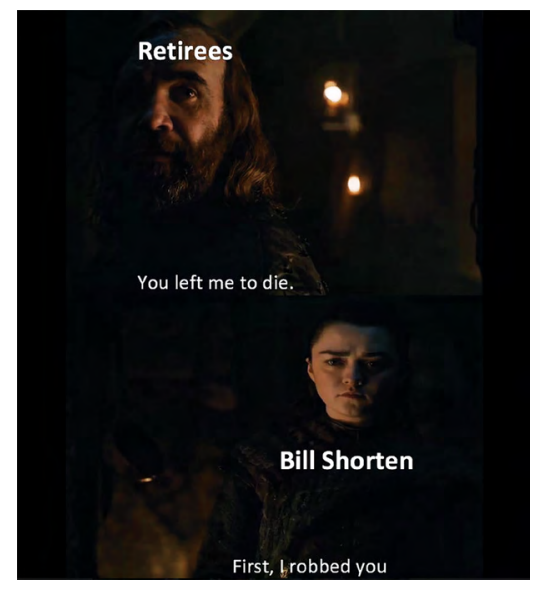

Plate 24.26 Meme by Innovative and Agile Memes

Source: Facebook, 18 May 2019.

\section{Franking credits}

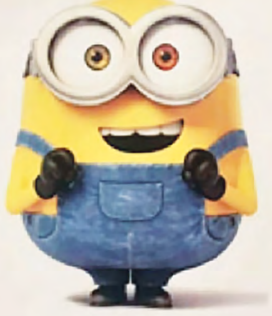

are a tax refund on tax you never paid, and we need that money to pay for hospitals and shit

Plate 24.27 888 Memes for Oldest Continuously Functioning Trades Hall Teens, 'Franking credits'

Source: Facebook, 9 May 2019. 


\section{Preferences}

While the question of preferences was of no discernible interest to internet satirists, a suite of 25 cartoons interrogated the spectacle of Clive Palmer's $\$ 60$ million intervention in the campaign. Brisbane's The CourierMail unsurprisingly focused on Palmer's failure to pay entitlements to Queensland Nickel workers, while other newspapers looked at how the flow of UAP preferences to Morrison might impact the election result and what concessions might be demanded in return. The Hobart Mercury's Christopher Downes channels Norman Rockwell in a beautifully rendered image showing a nervous Morrison observing Palmer's political track record (Plate 24.28), while Rowe pairs Palmer with the embattled Pauline Hanson in illustrating Morrison's poll-driven compromise (Plate 24.29).

Ultimately, UAP and PHON preferences in Queensland contributed to a 9 per cent swing to the Coalition in the five 'Adani seats' (see Chapter 11, this volume). In the lead-up to polling day, a prescient Mark Knight cartoon employs the metaphor of a topical Australian Football League controversy in describing the impact of Palmer's campaign on Shorten's prime ministerial ambitions (Plate 24.30); while in the aftermath of the election, Pope summarises the irony of a political party leader achieving his policy ambitions despite not having secured a single seat (Plate 24.31).

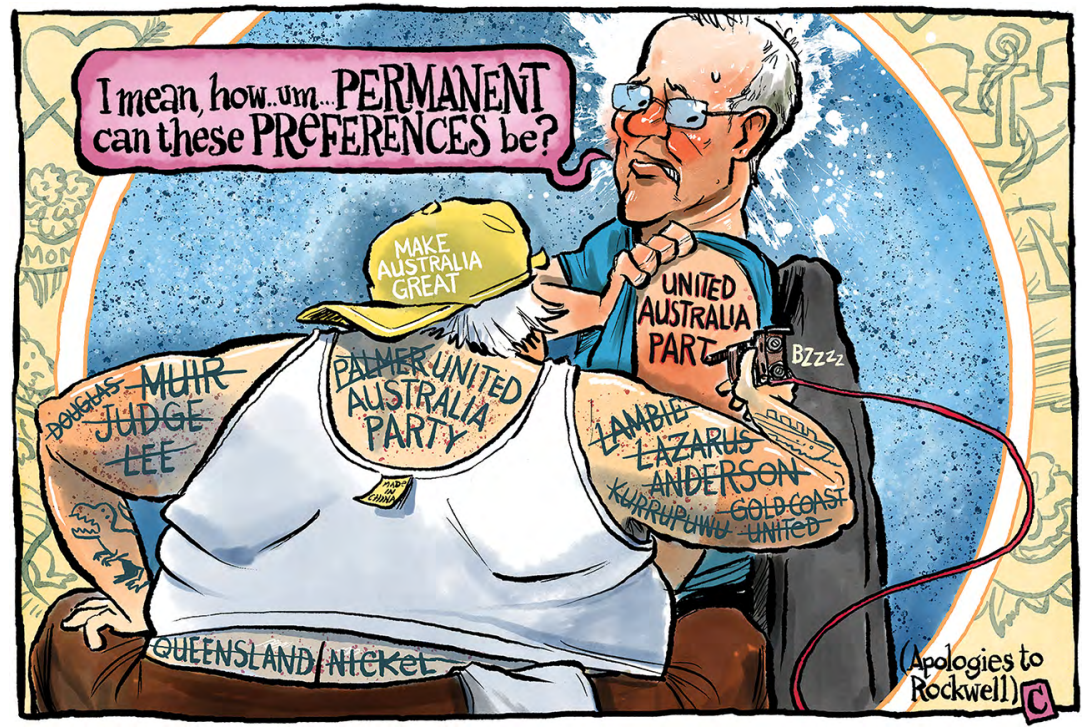

Plate 24.28 Cartoon by Christopher Downes

Source: Mercury, [Hobart], 30 April 2019. 


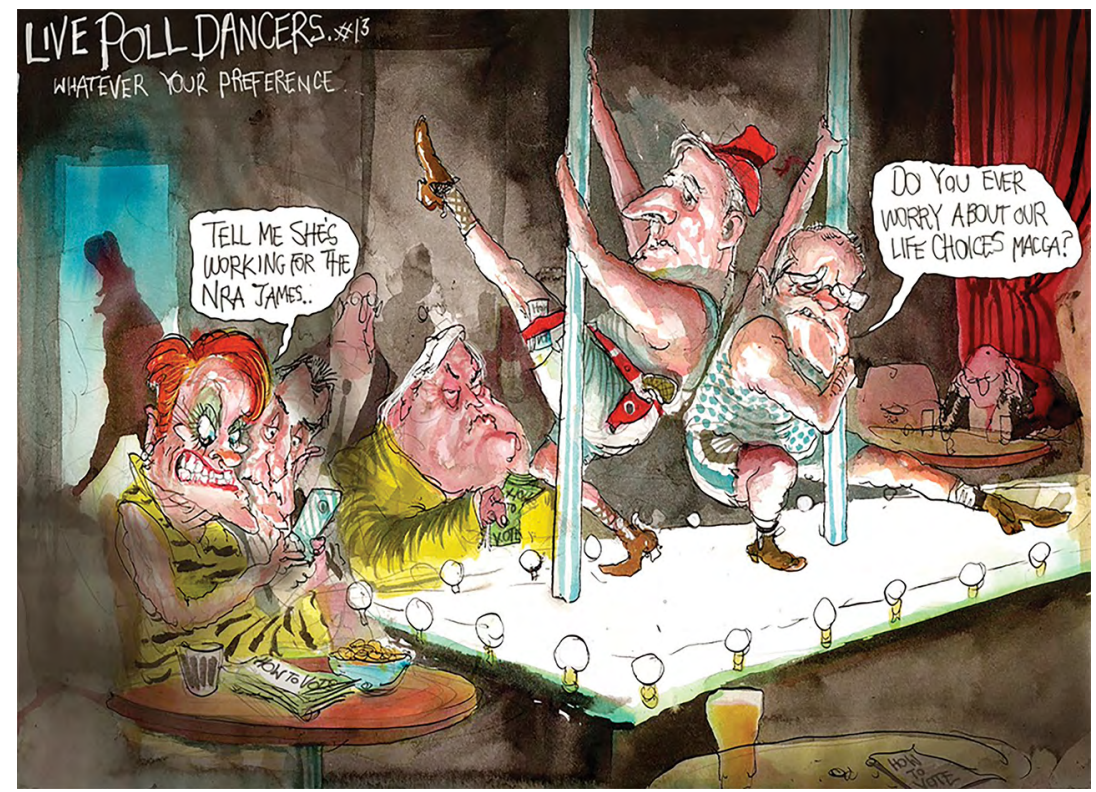

Plate 24.29 David Rowe, 'Live poll dancers'

Source: Australian Financial Review, 1 May 2019.

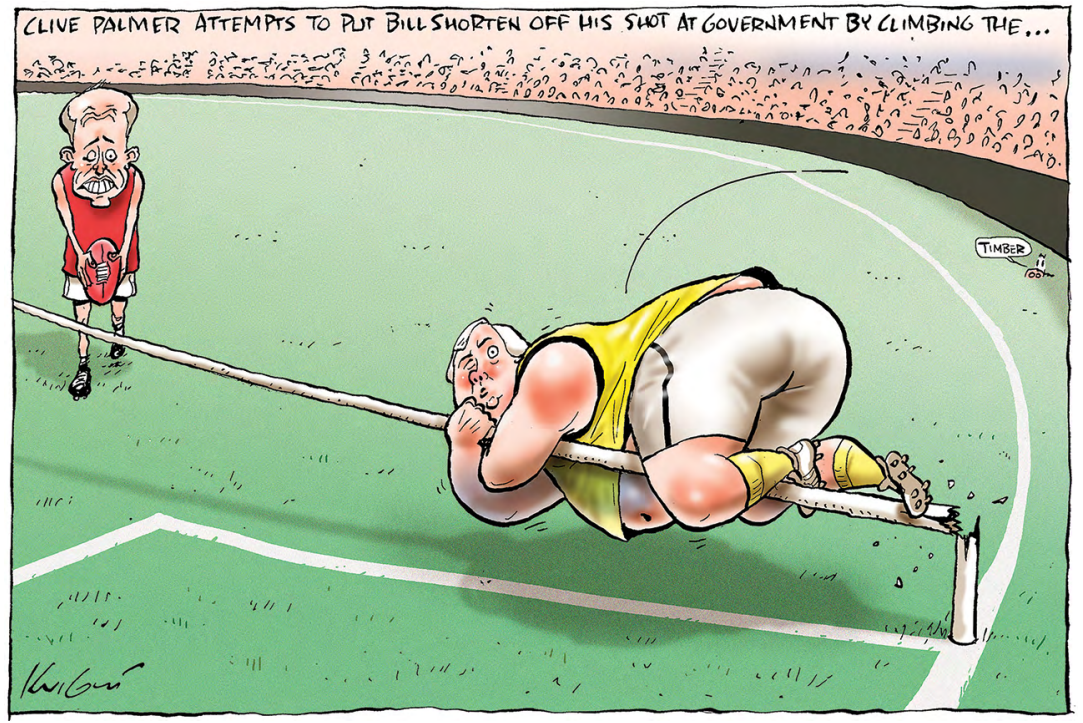

Plate 24.30 Cartoon by Mark Knight

Source: Herald Sun, [Melbourne], 14 May 2019. 


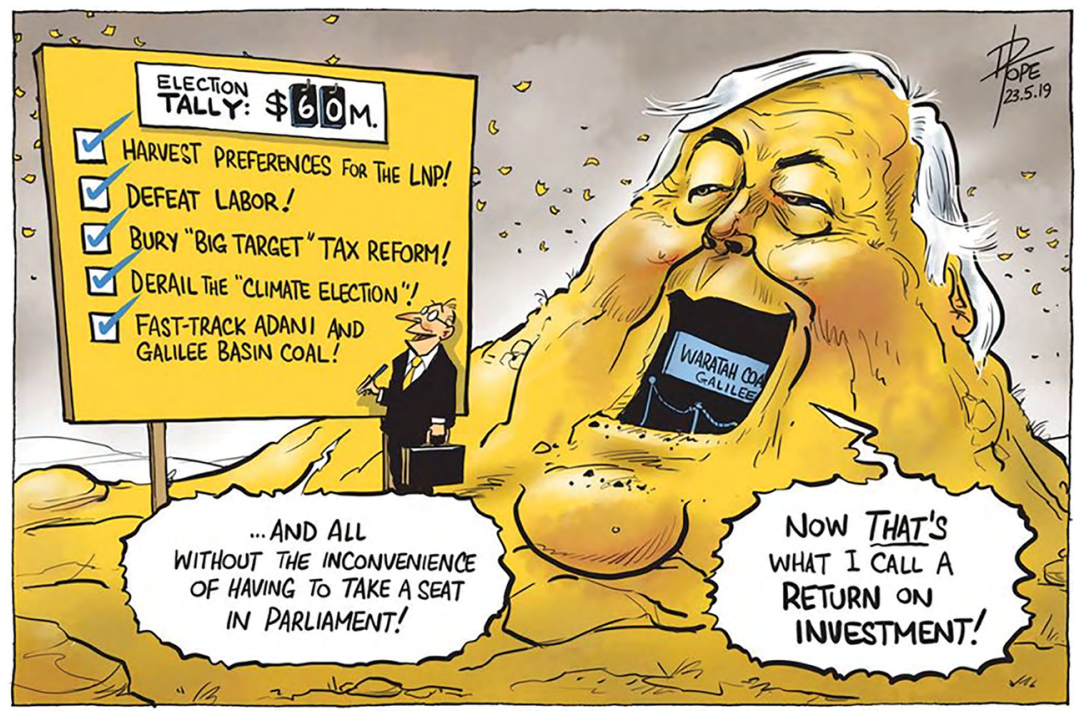

Plate 24.31 Cartoon by David Pope

Source: The Canberra Times, 23 May 2019.

\section{The outcome}

As seen in preceding chapters, Labor failed to make a compelling case for change. Despite a host of Coalition failures and missteps in government-articulated in excoriating detail in The Juice Media's 'Honest Government Ad: 2019 Election' viral video (Plate 24.32) Labor was unable to match Morrison's strong messaging (see Chapter 23, this volume). ABC TV video editor Huw Parkinson's take on the election, published on polling day, was conceived at least one week before the result was known - and yet the metaphor he chose to frame the election was, very aptly, the Back to the Future movie trilogy (Plate 24.33). While Parkinson had his tongue firmly in his cheek, Scott Morrison was deadly serious when he announced in a debate few cared about that he had 'brought the Budget back to surplus next year' (ABC 2019b). 


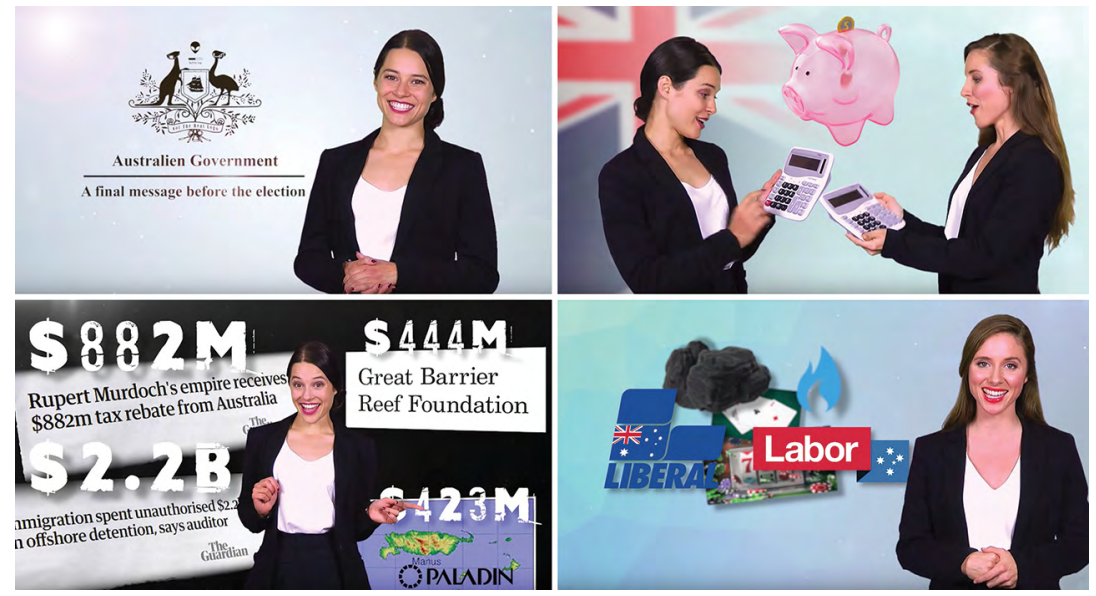

Plate 24.32 Still showing an image sequence from The Juice Media's mash-up video, 'Honest Government Ad: 2019 Election', 6 May 2019

Source: www.youtube.com/watch?v=OJrXI3rBbSA\&t=3s.
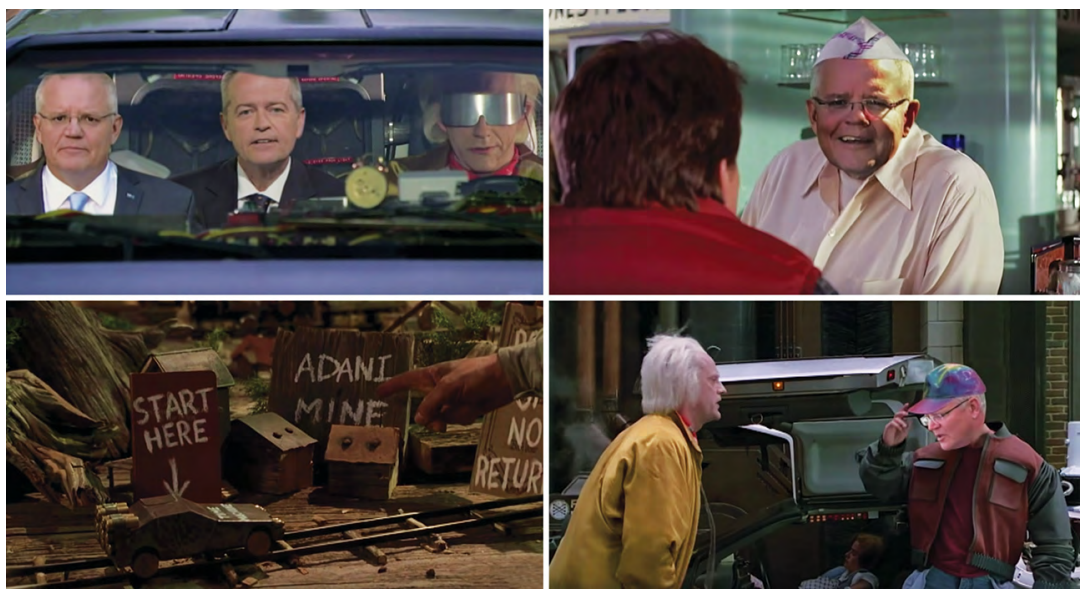

Plate 24.33 Still showing an image sequence from Huw Parkinson's mash-up video, 'Back to the Polls', 18 May 2019

Source: www.youtube.com/watch?v=cp_AdOG-X_k. 


\section{Conclusion}

The above examples demonstrate the various ways in which cartoons, memes and videos responded to the key themes and developments of the federal election. The cartoons-authored by professional satirists and located in immediate textual proximity to the reported news of the moment - covered a broad range of campaign topics and were acutely responsive to events playing out within the 24-hour news cycle. A crossplatform newspaper readership of around 16 million suggests that reports of their demise are an exaggeration-but perhaps only slightly. For example, the audience trend is away from print media and towards online editions where the cartoon does not enjoy the same prominence on the op-ed page. Inevitably, if not already, they will give way to memes and videos as the default satirical images. The memes circulating throughout the campaign were narrower in topical scope than the cartoons and distilled the concerns of the electorate into the issues of taxation, the economy, climate change, Liberal leadership and voter distrust of Bill Shorten. Interestingly, Andrea Carson and Lawrie Zion write in Chapter 22 (this volume) that the front-page stories appearing in Australia's major daily newspapers were-with the notable exception of Liberal leadership—-dominated by much the same topics. At their best, memes can be an effective satirical and democratic tool through their participatory modes of production and dissemination. They can promote broad public discourse and scrutiny of political players by mirroring some voter sentiments and highlighting policy positions. The temporal nature of videos makes them more labourintensive to produce than cartoons and memes, but also affords a more expansive canvas on which to lampoon their targets. The adverse public response to the video satire produced by political lobby groups presents a cautionary note for would-be satirists promoting a partisan agenda.

The increasing prominence of memes in democratic discourse raises some interesting points for discussion that are beyond the scope of this chapter. For example, political players and citizen comics alike now share a common publication and communication platform. The proliferation and weaponisation of memes produced and disseminated by partisan groups, rather than engaged citizens, are blurring the lines between propaganda, advertising and journalism-and may have significant implications for satire specifically and democratic discourse more broadly. In addition, the capacity for memes to reinforce insular online communities (or 'echo chambers') and promulgate misinformation is an 
emerging field of research that, in light of the 'death tax', has particular relevance to this campaign. Notwithstanding these concerns, when viewed collectively, the visual satire produced and disseminated throughout the campaign not only presented a clear and critical engagement with the events as they transpired, but also provided a reliable gauge of the electoral mood. Consequently, the body of satirical work can reasonably be seen as having succeeded as one of the more dependable predictors of the final result when many of the traditional indicators got it so famously wrong. After a campaign in which the two major parties presented the clearest policy differences in decades, voters decided they were not that interested in either of them. The result seemed to surprise a great many people. Looking over their aggregated contributions to the election campaign, it's difficult to imagine that the satirists were among them.

\section{References}

Australian Broadcasting Corporation (ABC). 2019a. ABC News, [ABC TV], 8 April.

Australian Broadcasting Corporation (ABC). 2019b. Australia Debates: Leaders' Debate, [ABC TV], 24 April.

Australian Broadcasting Corporation (ABC). 2019c. 'Beetaloo Basin gas project emissions could dwarf Adani, experts warn'. RN Breakfast with Cathy Van Extel, [ABC Radio], 14 May. www.abc.net.au/radionational/programs/breakfast/ beetaloo-basin-gas-project-emissions-would-dwarf-adani/11110200.

Coughlan, Matt. 2019. 'Shorten's mood for change on election day'. The Canberra Times, 18 May.

Dean, Jonathan. 2018. 'Sorted for Memes and Gifs: Visual Media and Everyday Politics'. Political Studies Review 17(3): 255-66. doi.org/10.1177/ 1478929918807483.

Flew, Terry. 2008. 'Not Yet the Internet Election: Online Media, Political Commentary and the 2007 Australian Federal Election'. Media International Australia 126(1): 5-13. doi.org/10.1177/1329878X0812600103.

Graeff, Erhardt. 2015. 'Binders full of election memes: Participatory culture invades the 2012 U.S. election'. Civic Media Project, 10 March. Cambridge, MA: MIT Media Lab. www.media.mit.edu/publications/binders-full-of-election-memesparticipatory-culture-invades-the-2012-u-s-election/. 
Koslowski, Max. 2019. 'The expert who predicted Trump, Brexit-and Scott Morrison'. Sydney Morning Herald, 19 May.

Purcell, Charles. 2015. 'How the power of the meme brought down Bronwyn Bishop'. The Walkley Foundation, 4 August. www.walkleys.com/how-thepower-of-the-meme-brought-down-bronwyn-bishop/ [page discontinued].

Renner, Nausicaa. 2017. 'Memes trump articles on Breitbart's Facebook page'. Columbia Journalism Review, 30 January. www.cjr.org/tow_center/memestrump-articles-on-breitbarts-facebook-page.php.

Rentschler, Carrie and Samantha Thrift. 2015. 'Doing Feminism in the Network: Networked Laughter and the "Binders Full of Women" Meme'. Feminist Theory 16(3): 329-59. doi.org/10.1177/1464700115604136.

Ross, Sheryl Tuttle. 2002. 'Understanding Propaganda: The Epistemic Merit Model and Its Application to Art'. The Journal of Aesthetic Education 36(1): 16-30. doi.org/10.2307/3333623.

Seven Network. 2019. Sunrise, [7Plus Television], 5 May.

Tay, Geniesa. 2014. 'Binders full of LOLitics: Political Humour, Internet Memes, and Play in the 2012 US Presidential Election (and Beyond)'. European Journal of Humour Research 2(4): 46-73. doi.org/10.7592/EJHR2014.2.4.tay.

Turton, Shaun. 2015. 'How social media destroyed an Australian politician'. Revolution Digital, [Blog], 4 August. www.revolutionweb.com.au/social-media/ how-social-media-destroyed-an-australian-politician/.

Williams, Paul. 2008. 'The 2007 Australian Federal Election: The Story of Labor's Return from the Electoral Wilderness'. Australian Journal of Politics and History 54(1): 104-25. doi.org/10.1111/j.1467-8497.2008.00487.x. 
This text is taken from Morrison's Miracle: The 2019 Australian Federal Election, edited by Anika Gauja, Marian Sawer and Marian Simms, published 2020 by ANU Press, The Australian National University, Canberra, Australia.

doi.org/10.22459/MM.2020.24 